【論文】

\title{
大学におけるリサイクル市の中断，再起 および継続運営に関わる要因分析
}

\author{
井山慶 信 ${ }^{*}$ - 竹 田 慶 ${ }^{* *}$ - 早 瀬 光 司 *
}

【要 旨】多くの大学で「リサイクル市」が実施されているが, 継続阻害要因が多数存在し広島大学で あ 2000 年に一時中断した。過去の運営デー夕を収集し分析した結果，スタッフ不足による「肉体的疲 労」の增大, 来場者殺到による「精神的疲労」の増大, 疲労の大きさに対する「満足感・達成感」の不 足という三点の継続阻害要因が示された。この三点への対策として「スタッフ募集の強化」「来場者の 分散」「寄付という新たな目標の設定」を行い 2001 年にリサイクル市を再起した。スタッフ数增加によ り肉体的疲労は軽減され，寄付という社会貢献の実施により満足感・達成感も向上したが，来場者殺到 による精神的疲労は改善されなかった。そこで 2002 年は「抽選方式による購入」や「睡入者を学生に 限定」など改善策を導入し精神的疲労も解決することができた。広島大学での分析結果を基に他の大学 でも参考となりうるリサイクル市継続運営チェックシートも作成できた。

キーワード：リサイクル市, リュース, 阻害要因, 継続運営, 大学

\section{1.はじめに}

地球環境問題が深刻となっている現在, 様々な環境負 荷削減のための取り組みが行われてきている。特に廃棄 物問題に関しては,「大量生産，大量消費，大量廃棄」 型の経済社会から脱却し, 環境への負荷が少ない「循環 型社会」を形成することが急務とされている(-9)。その ため,「循環型社会形成促進基本法 ${ }^{10,11} 」 か ゙ 2000$ 年 6 月 に公布され，そこでは「循環資源の全部又は一部のうち， 再使用をすることができるものについては，再使用がさ れなければならない(10,11)」と規定されている。他にも，

「資源の有効な利用の促進に関する法律（資源有効利用 促進法 $)^{10,11)}$ 「容器包装に係る分別収集及び再商品化の 促進等に関する法律（容器包装リサイクル法 $)^{10,11)} 」 「$ 特 定家庭用機器再商品化法 (家電リサイクル法 $)^{10,11}$ 」な

原稿受付 2003.9.27原稿受理 2004.2.10

* 広島大学大学院 生物圈科学研究科

** 広島大学 総合科学部

連絡先: $7739-8521$ 広島県東広島市鏡山 1-7-1 広島大学大学院 生物圈科学研究科 早瀬研究宾 井山慶信 E-mail : khayase@hiroshima-u.ac.jp
どのリユース,リサイクルに関する法制度および社会シ ステムも徐々に整い始めている。

このような状況の中, 大学においては毎年, 卒業・入 学時期に, 独り暮らしを終えた卒業生が大量の生活用品, 家電製品などを粗大ごみとして排出し, 逆に独り暮らし を始める新入生は同様の製品を新しく購入するという現 象が繰り返されている。ここでの物の流れに着目し, 環 境負荷削減の取り組みとして行われているのが,「リサ

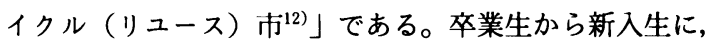
まだ十分使える物品を橋渡しすることにより, 環境面で 廃㙌による負荷と製造による負荷の両方を同時に削減す ることができ，また経済面でも新生活開始時の出費を削 減できるという利点もある。「リサイクル市」の取り組 みは全国の大学に広がっており, 実施大学は京都大学 ${ }^{12)}$ を始め二十数大学に及んでいる。また，実施していない 地域での卒業生, 新入生に対するアンヶートによると, リサイクル市のようなリサイクルシステムに対する関心 は非常に高く ${ }^{13)}$, 今後リサイクル市の必要性はさらに增 していくと考えられる。 


\section{2. 目的}

多くの大学で「リサイクル市」は, 学生で構成された 実行委員会や環境サークルが中心となって運営を行って いる。運営を学生が行っているため, 必ずスタッフの入 れ替わりがあり, 組織として運営メンバーの維持やボラ ンティアの募集, 大学との協力, 当日の負担, 業務の引 き継ぎなどの点で, 継続を困難とさせる要因が多く存在 している。広島大学では, 環境問題に関心のある学生が 作っている総合環境サークル「EcoPage」が, 環境負 荷削減を目的に 1997 年 4 月「広島大学リサイクル市」 を立ち上げることができ ${ }^{14)}, \quad$ そ後 $1998 ， 1999$ 年は継 続して運営することができた。しかしながら 2000 年は 継続運営が困難な状況が生じ中断された。大学でのリサ イクル市立ち上げの側面に関する分析は報告されている

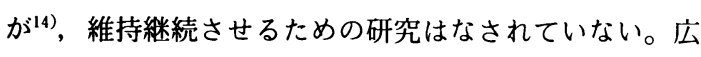
島大学のみならずリサイクル市を中断する大学あいくつ か現れているため, リサイクル市の維持継続のための研 究が必要である。

本研究では広島大学を一つの実験系として，大学にお けるリサイクル市の継続が困難となった要因を人的負担 や経済的側面などの様々な観点から分析・抽出し， 2001 年に再びリサイクル市を立ち上げ，その際に試行する改 善策の効果について検証することを目的とする。立ち上 げ継続運営した経過から継続阻害要因を再分析して整理 し, 他の大学であ参考となりうるリサイクル市継続運営 チェックシートを作成する。

\section{3. リサイクル市の中断}

\section{1 リサイクル市の経緯（1997 年〜 1999 年）}

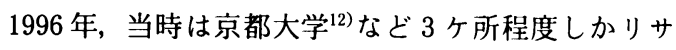
イクル市を行っていない状況において，広島大学では総 合環境サークル「EcoPage」(当時スタッフ7名)がリサ
イクル市の企画，交涉を行い，1997年 4 月に実施した ${ }^{14)}$ 。 その後もこの環境サークルの中心的イベントとして, 1998, 1999 年とリサイクル市を企画し, 物品を提供した。 しかし，1999 年のリサイクル市終了後, EcoPage の活 動は休止し，他の団体が企画することもなかったため， リサイクル市は結果的に 3 年で中断してしまった。

\section{2 リサイクル市中断の要因分析}

3.2.1 過去の運営状況のデー夕収集とスタッフへの聞 き取り

インタビューの手続きとして 2000 年 11 月, 前報 ${ }^{14)}$ の 筆者であり 1997 年リサイクル市のリーダーである吉田 宣幸氏に連絡を取り，吉田氏を通じて 1998，1999 年の リーダー, 吉田氏を含む計 3 名に対し, リサイクル市で の物品・業務・指示の流れや, 運営状況に関するデー夕 （物品保管場所, 運搬手段, 会計収支, 提供物品数, 物品 提供者数, 来場者数, スタッフ数, 開(催日数), リサイク ル市実施後の状況（会場の需网気, スタッフの疲労度や 感想, 運営での良かった点, 悪かった点など）について, アンケートを郵送し，その後詳細について電話で聞き取 りを行った。リサイクル市の全体を把握するため Fig. 1 にスタートから終了までの物品・業務・指示の流れを 示した。また, Table 1 に物品保管場所, 運搬手段, 物 品提供者数, 来場者数, スタッフ数, 開催日数の推移を 示し，Fig. 2 に収入，倉庫に関する支出，倉庫代を除 く支出と提供物品数の継年変化を示した。Table 1, Fig.

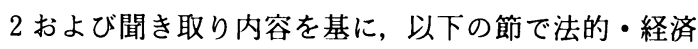
的・人的の 3 つの側面から継続阻害要因について分析し 考察する。

\section{2 .2 法的側面からの要因分析}

1999 年まで法的問題は無く ${ }^{14)}, 2000$ 年に新しい法律 ができた訳でもない。家電リサイクル法に関しても 2001 年 4 月に施行であり, 2000 年の段階では影響を受 けていないため, 法的要因による中断ではなかった。

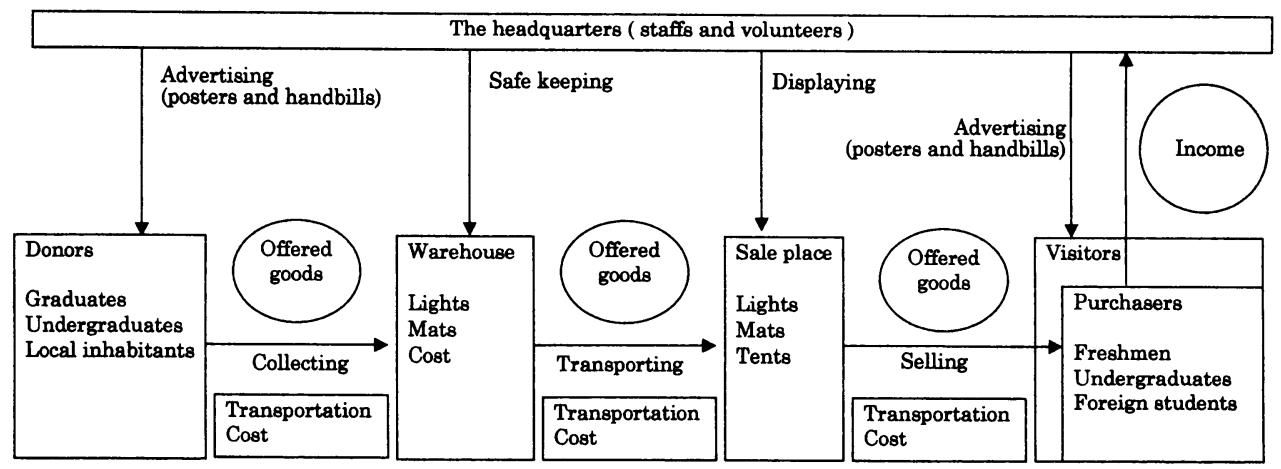

Fig. 1 The flow of a recycle market 
Table 1 Situations of recycle markets at Hiroshima University

\begin{tabular}{|c|c|c|c|c|c|}
\hline year & 1997 & 1998 & 1999 & 2001 & 2002 \\
\hline warehouse & $\begin{array}{c}1 \text { site } \\
\left(\text { an enterprise }{ }^{* 1}\right)\end{array}$ & $\begin{array}{c}3 \text { sites } \\
\text { (a university }{ }^{* 1} \\
\text { an elementary } \\
\text { school*1 } \\
\text { an enterprise) }\end{array}$ & $\begin{array}{c}1 \text { site } \\
\text { (an enterprise) }\end{array}$ & $\begin{array}{c}2 \text { sites } \\
\text { (a university*1 } \\
\text { an enterprise) }\end{array}$ & $\begin{array}{c}2 \text { sites } \\
\text { (a university }{ }^{* 1} \\
\text { an enterprise) }\end{array}$ \\
\hline transportation & $\begin{array}{c}2 \text { cars } \\
\text { (a university*1 } \\
\text { an enterprise) }\end{array}$ & $\begin{array}{c}3 \text { cars } \\
(\text { a university*1 } \\
2 \text { enterprises) }\end{array}$ & $\begin{array}{c}2 \text { cars } \\
\text { (a university*1 } \\
\text { an enterprise) }\end{array}$ & $\begin{array}{c}2 \text { cars } \\
\text { (a university*1 } \\
\text { an enterprise) }\end{array}$ & $\begin{array}{c}3 \text { cars } \\
\text { (a university }{ }^{* 1} \\
2 \text { enterprises) }\end{array}$ \\
\hline the number of donors & 52 & 111 & 81 & 77 & 143 \\
\hline the number of purchasers & 157 & 177 & 97 & 177 & about 200 \\
\hline the number of staffs ${ }^{* 2}$ & 7 & 6 & 6 & 15 & 24 \\
\hline the number of sale days & 3 & 3 & 2 & 2 & 2 \\
\hline
\end{tabular}

* 1 : free of charge

* 2 : excepting volunteers

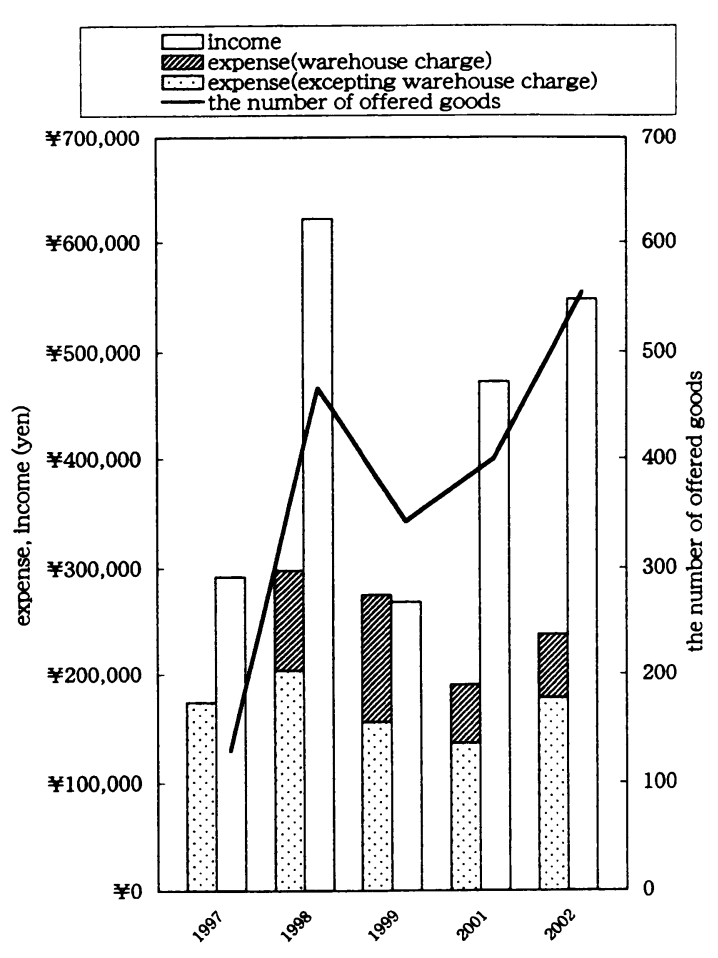

Fig. 2 Annual expense, income and the number of offered goods

\section{2 .3 経済的側面からの要因分析}

Fig. 2 に示したように, 提供物品数は, 1997 年 ${ }^{14)}$ は 最初の年であったため比較的少なかったが, 1998, 1999 年は 1997 年の 2 倍以上に増加しており, 数量として十 分な量が継続して提供されている。提供物品数が極端に 少なければリサイクル市の継続が困難となるが, 大学内 での認知度も高まっていたため, その後も一定以上の提 供数が見込める状況であった。また会計収支に関しても， 倉庫の費用を除いた支出額は大きく変化しておらず, こ
の支出はレンタカー代, ガソリン代, 電話代が主であり 定常的なものである。そして倉庫を含めた支出額も, 売 上で十分カバーすることができていた。リサイクル市は 営利目的でないため, あともと黒字を極力抑えるような 料金設定（新品価格の 1 割程度）をしており，それでも 98 年には収入があまりにあ多過ぎたため 99 年は売り值 を調整して収支をゼロに近付けたという状況であった。 価格が安いため少々值上げをしてあ売れ行きに影響はな いので, 仮に支出が増える場合があっても対処できる余 裕が十分あった。以上のことから経済的側面での中断で はなかったということができる。

\subsection{4 人的側面からの要因分析}

では何が中断の要因であったのか。1999年の運営代 表者へのインタビューおよびアンヶート調查より, 組織 が消滅した理由として「後任者がいなかった」との回答 をもらった。また，リサイクル市を継続させていく上で 一番ネックとなることは「中心となる人（組織）の継続 性」であることがわかった。スタッフおよび中心的人材 の確保が, 継続する上での重要な要素であると確認され た。

また, 運営上の課題として, スタッフの肉体的疲労や 精神的疲労の大きさがあげられていた。満足度や疲労度 に関して 1997 年〜 1999 年の代表者らに 5 段階評価で質 問したところ, 満足度は 3 (普通), 肉体的㽻労度は 4 (疲れた), 精神的疲労度は 4 (疲れた） 5（大変疲れ た）という答えであった。疲労がひどかった理由として 「仕事の量がスタッフのキャパシティを超えていた」こ とがあげられていた。

肉体的疲労を見るために, 労働量の原単位として, Fig. 3 にスタッフー人あたりの提供物品数を示した。 1997 年に比べ 1998, 1999 年はスタッフ数が減少してい るにもかかわらず, Fig. 2 に示したように提供物品数 が増加したため, 労働原単位が大幅に増加した。労働原 


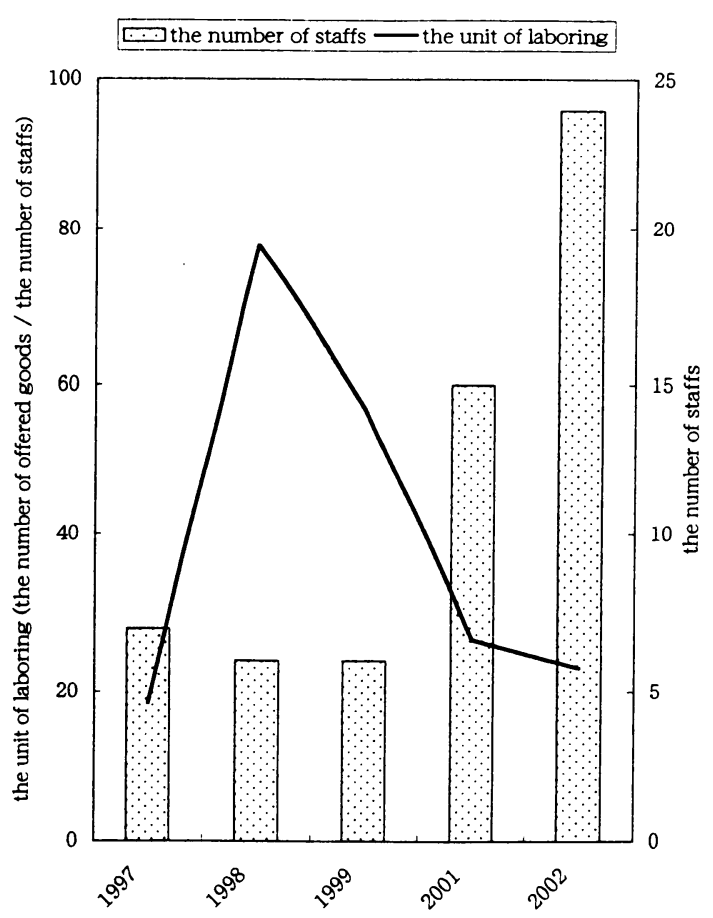

Fig. 3 The unit of laboring

単位が低かった 1997 年 ${ }^{14)}$ でさえ当時の代表者は,「事業 での大きな疲労感と新スタッフ確保の難しさ」を痛感し ており, 継続性に関しては限界を感じていたことがわ かった。このことが, 上で述べた肉体的疲労の増加を指 し示している。

また, リサイクル市当日はバーゲンセールに似た殺到 して押し寄せるような雾囲気があり，それがスタッフに 大きな精神的疲労を与えていた。それは購入方法が物品 䗰入申込書に物品番号を記入し, 先に提出した者から購 入できる「早い者勝ち」方式であったため, 安くて質の 良いあのを我先に手に入れようと開催直後から客が殺到 し、スタッフと客および客同士のトラブルが発生してい たからである。スタッフにとって金銭を储けることがリ サイクル市の目的ではなく, 和やかな雾囲気の中で新入 生にゆっくり楽しんで商品を選んであらうことを前提と していたので, 混雑や喧騒, トラブルなどが生じた現実 とスタッフの前提との間にギャップが生じ, 精神的疲労 の要因となっていた。聞き取りであ，「初めて参加する スタッフにとっては, 喧騒や騒音などの精神的ショック が非常に大きかった」という意見が出ており，来場者の 殺到という精神的疲労が中断要因の主要な一側面である ことがわかった。

さらに, 1997 年〜 1999 年はリサイクル市を実施する ことのみが活動の目的であったため, 終了後スタッフは
疲れただけで満足感・達成感が薄かったことがインタ ビューによりわかった。収益があったにあかかわらず満 足感・達成感が薄かったのは, 収益の使い道がなかった からと考えられる。1998, 1999 年は大きくなり過ぎた収 益を消費するために, 急遽スタッフの疲労に対する補助 として収益の多くを弁当代などに割り当てた。しかし， この行為は満足感・達成感の向上にはつながらなかった。 収益をバイト代としてスタッフ全員に分配するという案 あ出たが，金銭目的で活動している訳ではなくそれには 反対の意見が多く, 分配することも満足感・達成感の向 上にはつながらなかった。収益金の活用などリサイクル 市実施以外の目的が無かったことによる満足感・達成感 の不足も中断要因の一つであることがわかった。

このように 1998, 1999 年と肉体的疲労・精神的疲労の 原因が解決されず満足感・達成感の向上屯得られなかっ たため, 人材を確保することが困難となりリサイクル市 が中断したと考えられる。いかに施設や提供物品数, 利 益が十分にあろうと，根源的に人的側面を十分考慮に入 れて活動しなければ, 肉体的疲労および精神的疲労が大 きくなり継続が困難になることが示された。肉体的疲労 および精神的疲労を軽減させスタッフが効果的に満足 感・達成感を得られるようにすることが, 人材を確保し リサイクル市を継続させていくために必須である。

\section{4. リサイクル市の再立ち上げ（2001 年）}

2000 年 11 月, 環境問題に関心があり何か行動をした いという有志たちが新たな環境サークル「えこ・ペー じ」を結成し, サークルの企画の一つとして, 中断して しまった広島大学リサイクル市を再び実施しょうと活動 が始まった。過去のリサイクル市を経験したことのある スタッフは全くいなかった。このサークルのリーダーで ある参与者の竹田と参与者でない研究者井山, 早瀬は 3. 2 で分析したリサイクル市継続阻害要因に対して改善の ためのいくつかの仮説を立て, 再立ち上げを行った際に どのような効果があるか検証を試みることとした。

リサイクル市再起にあたり, 継続阻害要因である「肉 体的疲労」「精神的疲労」「満足感・達成感の不足」への 対策として, 以下の運営改善を行った。

まず「肉体的疲労」への対策として, スタッフの数を 十分に確保するため, 新たなスタッフやリサイクル市当 日の前後で手伝ってくれるボランティアの募集に力を入 れることにした。アルバイトのスタッフを雇うという案 ああったが， あくまでも利益目的の活動ではないことと 仲間同士の一体感を大切にしたいということからボラン ティアという形にした。さらに, スタッフの役割を明確 
化し効率的に運用するため，全員を「宣伝」「会計」「回 収」「管理」「配達」「当日企画」の 6 つの係に分担し, 互いに進行状況を把握しながら, 係毎に業務を進めてい くこととした。タイムテーブルや簡易マニュアルも作成 した。

「精神的疲労」に対しては, 最もストレスの大きい 「バーゲンセールのような来場者の殺到」を緩和するた め, 物品の配置場所を拡大し, また物品の展示数も午前 と午後に配分することにより，混雑を分散させることと した。さらに開催途中から，物品と来場者との間にロー プを張り，離れたところから物品を見てもらうようにし た。価格の基準は原価の約一割に設定し，50 円均一や 無償提供のコーナーも設置した。

「満足感・達成感」を向上させるため，収益を環境保 護や災害援助活動を行っている NGO 3 団体に寄付する こととした。環境負荷削隇という目的の他に, 社会貢献 にあたる「寄付」という新たな目標を設定し，それを目 指して運営を行うこととした。これはもともと金銭目的 の活動ではなかったので，寄付という形になった。

\section{5.リサイクル市運営改善効果の検証と考察 (2001 年)}

2001 年 4 月に新たなりサイクル市を実施させること ができた。スタッフ数は過去 3 年の 6 〜 名から 2001 年は 15 名と，倍以上確保することができた。そのため 提供物品数の増加にあ対応でき，Fig. 2 に示すように 1998 年や 1999 年よりも労㗢原単位を半分以下に軽減す ることができた。また，スタッフの役割や責任を分担さ せたことにより，負担が一人に集中することもなく，肉 体的疲労を大幅に軽減でき有効であった。

精神的疲労の主要因である「来場者の殺到」への対策 として, 販売会場の拡大による物理的分散と, 物品の時 間差展示による時間的分散を試みたが，2001 年も来場 者による殺到・混雑は激しく，精神的疲労改善の効果は あまり示されなかった。精神的疲労の軽減に関しては 2002 年以降でさらなる対策が必要となった。

満足感・達成感への対応として, 寄付という社会的貢 献を第二の目的とすることにより最終的に 21 万円すの 寄付を行うことができた。リサイクル市の成功と廃棄物 削減による環境への貢献に加え社会的貢献も十分に達成 できたことにより，スタッフの満足感・達成感は以前よ りも向上した。

\section{6. リサイクル市継続運営の成功（2002 年）}

2001 年のリサイクル市再起を踏まえ， 2002 年はさら に改善を加えた上で実施した。主な改善点とその効果に ついて以下に述べる。

最も改善が必要な点は, スタッフの精神的疲労の原因 である「来場者の殺到」であった。回避する取り組みと して, 物品（小物を除く）の購入方法を「早い者勝ち方 式」から「購入希望者の中から抽選で決定する方式」に 変更し, 購入者も今までの「無制限」から「学生のみ」 に制限した。抽選については 1 家族につき 1 枚の番号札 を配付し，午前と午後に分けて抽選を行った。これによ り急いで購入する必要が無くなったため来場者はじっく り選ぶことができ，会場の雾囲気も秲やかなあのとなっ た。精神的疲労の解決において抽選方式は非常に効果的 であった。また，購入者を「学生のみ」に制限すること により，学生同士の落ち着いた雾囲気を作り出すことが できこのことも来場者の殺到を回避することに貢献し た。

肉体的疲労に関しては，2001 年の経験を基に係每の マニュアルや管理ノートなどを作成した。マニュアルが あることで初めてのスタッフであ仕事を確実に把握し効 率的に動くことが可能となった。また，Table 1 と Fig. 2 に示すように物品提供者数や提供物品数は今ま での最高値となっていたが，スタッフ数の増加により Fig. 3 に示したように労働原単位は 2001 年よりも減少 し，肉体的疲労の問題も発生しなかった。さらに2002 年から会場を屋内に移したことにより，天候による影響 がなくなり会場設営や商品搬入の点でも負担は軽減され た。

満足感・達成感については, 寄付に関しては継続して 行っているためスタッフの満足感・達成感は向上した。 売上が増加しているので，寄付以外のさらなる活用方法 についてあ現在検討している。また，リサイクル市は人 と人とが強く関わる催しであるので，メッセージカード による言葉の橋渡しを物品提供者・リサイクル市スタッ フ・物品購入者の三者の間で行った。購入者にもスタッ フにもメッセージカードは非常に好評で，それが満足感 や達成感につながった。

「家電リサイクル法」の施行による対象物品の取り扱 いに関しては対策を講じた。2001 年 4 月の法施行後は, 家電四品目（テレビ，冷蔵庫，洗濯機，エアコン）を処 分する際，消費者は再資源化のためのコストを負担する ことが義務となった。そのため, 処分費用を浮かすため に廃棄同然の質の悪い物品がリサイクル市に提供される 可能性があった。2001 年までは受け取りに関する基準 
を設けなかったが, 2002 年からは新入生が卒業までの 4 年間使用することができるよう, 収集は原則的に 6 年 前までの年式に制限し，回収時の品質チェック・物品の 掃除の徹底・売れ残った場合の処理の仕方などについて あマニュアルを作成し対応した。その結果, 2002 年に 売れ残ったリサイクル家電は冷蔵庫 1 台のみであり, 有 償で処分した。

\section{7. 他大学でも参考となりうるチェックシート の作成}

大学の規模や特性によってリサイクル市の形態も様々 変化するが, 本研究での分析結果を基に, 一般の大学で あ参考となりうるリサイクル市継続運営のためのチェッ クシートを作成し Table 2 に示した。

肉体的疲労の軽減としては, スタッフや当日ボラン ティアの確保が最重要課題である。さらに, 大学や大学 生協之の協力体制確立や物品回収・配達の効率化も, 肉 体的疲労の軽減策として必要とした。精神的疲労の軽減 では, 来場者のコントロールが最も重要であり, 適切な 展示・販売方法を選択する必要がある。同様に, 新入生 が落ち着いた雾囲気でゆったり楽しく購入できる場を提
供することも重要とした。満足感・達成感の向上のため には, 収益の使い道や目的を明確にする必要がある。ま た,メッセージカードなどを用いて，物品提供者や購入 者およびスタッフの間でコミュニケーションをとること が, 満足感につながると考えられる。その他, 運営にお いて運搬手段之保管場所の確保は重要な要素である。さ らに, 提供物品の品質レベルを確保することも必要であ り, 家電リサイクル法への対応む今後さらに重要となっ $\tau く る 。$

以上のチェックシートを有効活用することにより，他 大学であ継続阻害要因を低隇し継続運営を可能にすると 期待される。

\section{8. まとめ}

過去の運営データを収集し分析した結果, 2000 年の 㕕島大学リサイクル市の中断は, 法的側面や経齐的側面 によるものではなく，「スタッフおよび中心的人材の不 足」という人的側面による中断であった。人材不足と なった要因が，スタッフ数の不足による「肉体的疲労」 の増大, 来場者の殺到による「精神的疲労」の増大, 疲 労の大きさに対する「満足感・達成感」の不足であるこ

Table 2 Check points for sustainable management of a recycle market

表 2 リサイクル市継続運営のためのチェックシート

\begin{tabular}{|c|c|}
\hline $\begin{array}{l}\text { purpose } \\
\text { 目的 }\end{array}$ & $\begin{array}{r}\text { check points } \\
\text { チェック項目 }\end{array}$ \\
\hline \multirow{3}{*}{$\begin{array}{l}\text { reduction of } \\
\text { physical tiredness } \\
\text { 肉体的疲労の軽減 }\end{array}$} & $\begin{array}{l}\text { Enough staffs and volunteers } \\
\text { スタッフ及び当日ボランティアの数が十分であるか。 }\end{array}$ \\
\hline & $\begin{array}{l}\text { Enough cooperation with university (ex. advertisement, sale place) } \\
\text { 宣伝や場所提供などについて, 大学や大学生協との協力体制ができているか。 }\end{array}$ \\
\hline & $\begin{array}{l}\text { High efficiency of collecting and delivering of offered goods } \\
\text { 物品の回収及び配達が効率良く行えているか。 }\end{array}$ \\
\hline \multirow{3}{*}{$\begin{array}{l}\text { reduction of } \\
\text { mental stress } \\
\text { 精神的疲労の軽減 }\end{array}$} & $\begin{array}{l}\text { Keeping visitors under control (ex. sale by lot) } \\
\text { 来場者をコントロールできているか（抽選方式や展示時間の分散など, 混雑が起こらない展示・販売方 } \\
\text { 法を採用しているか)。 }\end{array}$ \\
\hline & $\begin{array}{l}\text { Priority of freshmen } \\
\text { 新入生が優先して購入できているか（来場者の制限など）。 }\end{array}$ \\
\hline & $\begin{array}{l}\text { Good atmosphere of sale space } \\
\text { 会場の芬囲気は良いか。 }\end{array}$ \\
\hline \multirow{2}{*}{$\begin{array}{l}\text { improvement of } \\
\text { feeling of satisfaction } \\
\text { and achievement } \\
\text { 満足感・達成感の向上. }\end{array}$} & $\begin{array}{l}\text { Clear purpose and plan to use income (ex. contribution) } \\
\text { 収益の使い道や目的が明確であるか(寄付など)。 }\end{array}$ \\
\hline & $\begin{array}{l}\text { Good communication among donors, purchasers and staffs (ex. cards with message) } \\
\text { 提供者や購入者とのコミュニケーションが取れているか（メッセージカードの記入など)。 }\end{array}$ \\
\hline \multirow{5}{*}{$\begin{array}{l}\text { others } \\
\text { その他 }\end{array}$} & $\begin{array}{l}\text { Acquisition of convenient transportation（ex. a small truck） } \\
\text { 自由に利用可能な運搬手段（軽トラックなど）が確保されているか。 }\end{array}$ \\
\hline & $\begin{array}{l}\text { Acquisition of convenient warehouse (ex. area, distance from sale place, cost, business hours) } \\
\text { 保管場所が確保されており, 面積・会場との距離・費用・利用可能時間などについて問題が無いか。 }\end{array}$ \\
\hline & $\begin{array}{l}\text { Good quality of offered goods (ex. check of offered goods when collecting) } \\
\text { 物品の品質は良いか（提供者を学生に制限する，提供物品の年式や質の基準を設定する，などの対応)。 }\end{array}$ \\
\hline & $\begin{array}{l}\text { Enough measures against recycle law of electric appliances } \\
\text { 家電リサイクル法への対応ができているか（売れ残った場合の対策）。 }\end{array}$ \\
\hline & $\begin{array}{l}\text { Indoor sale place if possible } \\
\text { (可能ならば) 屋内の販売会場を確保できるか。 }\end{array}$ \\
\hline
\end{tabular}


とがわかった。リサイクル市の継続運営において「肉体 的疲労」「精神的疲労」「満足感・達成感」の三点に対す る改善は必要不可欠であり, 中断後の 2001，2002 年で はこれら三点の改善により継続阻害要因を大きく低減す ることができた。2003年の広島大学リサイクル市も, 上記要因の改善がさらに深化され，スタッフ・客とも非 常に穏やかでゆったりした雾囲気で順調に行われた。広 島大学での分析結果を基に, 他大学でも参考となりうる リサイクル市継続運営チェックシートあ作成できた。リ サイクル法の施行により「有償で処分するよりはまだ使 えるのでリサイクル市に提供しよう」という傾向が今後 強くなってきており，これから全国各地でこのようなリ サイクル市の輪が広がることが大きく期待される。

\section{考文献}

1）中村正子：面白読本どうするゴミ問題一大量浪費か らリサイクル社会へ, 柘植書房, pp. 68-69 (1991)

2）寄本勝美, 盛岡 通: 自治体・地域の環境戦略 4 省資源・リサイクル社会の構築, ぎょせい, pp. $308-$ 330 (1994)

3）和田安彦, 中野加都子, 山本良一：環境にやさしいラ イフスタイル—生活者のための社会をつくる, 技報 堂出版, pp. 1-19 (1996)
4）丸尾直美, 西ケ谷信雄, 落合由紀子：エコサイクル社 会, 有斐閣, pp. $1-5$ (1997)

5 ）社日本家政学会：ライフスタイルと環境, 朝倉書店, pp. $46-56$ (1997)

6 ）川名英之：どう創る循環型社会—ドイッの経験に学 ぶ, 緑風出版, pp. 14-46（1999）

7 ）吉村元男：地域発ゼロエミッション一廃棄物ゼロの 缃環型まちづくり，学芸出版社, pp. 2-4（2000）

8 ）酒井伸一, 森 千里, 植田和弘, 大塚 直: 復環型社会 一科学と政策, 有斐閣アルマ, pp. 1-340（2000）

9 ）武末高裕：環境リサイクル技術のしくみ, 日本実業出 版社, pp. 154-155（2002）

10）笹 徹：環境法と条例，日科技連出版社, pp. 147-197 (2001)

11）環境法令研究会 : 環境六法 一一平成 13 年度版, 中央 法規出版, pp. $1-2986$ (2001)

12）朝日新聞：新入生へ“下宿用品”リサイクル——年 10 年目の京大の「市」(京都), 朝日新聞 (1996.3.25)

13） RNECS（学生によるリサイクルネットワーク in せん だい：「学生とリサイクルとの関わり」についての 調查プロジェクト報告書 (2001) http: //rnecs.hp. infoseek.co.jp

14）吉出宣幸, 早瀬光司：大学におけるリサイクル市の立 ち上げとその法・経済的，人的および環境的側面に関 する研究, 咸裹物学会論文誌, 第 9 巻, 第 7 号, pp. $318-325$ (1998)

\title{
Analysis of Discontinuation, Recovery, and Sustainable Management Factors for a University Recycle Market
}

\author{
Yoshinobu Iyama*, Kei Takeda** and Kohji Hayase* \\ * Graduate School of Biosphere Sciences, Hiroshima University \\ ** Faculty of Integrated Arts and Sciences, Hiroshima University \\ ' Correspondence should be addressed to Yoshinobu Iyama: \\ Graduate School of Biosphere Sciences, Hiroshima University \\ (1-7-3 Kagamiyama, Higashi-Hiroshima, 739-8521 Japan)
}

\begin{abstract}
"Recycle markets" have been carried out at many universities, but due to the large number of prevention factors that continue to exist, the markets have been discontinued. The recycle market at Hiroshima University was stopped in 2000. After analyzing past data, results showed that the continuation of recycle markets were not feasible due to human conditions, such as staff numbers being insufficient; this was due to an increase in "physical exhaustion" and "mental stress" with a decrease in the "feeling of satisfaction and achievement." Three main problems had to be tackled in order to change the situation, so a campaign was developed in order to: 1 ) Recruit a robust volunteer staff ; 2 ) Welcome and manage visitors; and 3 ) Create a new purpose by showing that participation is a positive contribution, and the recycle market at Hiroshima University was restarted in 2001. Sustainable management of the recycle market was possible when these three factors were taken into consideration and tackled. The new-spirited Hiroshima University example can definitely be followed in order to continue markets at other universities too.
\end{abstract}

Key words : recycle market, reuse, prevention factor, sustainable management, university 